\title{
Chapter 7. Knowing Your Place: Representing relations of precedence and origin on the Buru landscape
}

\section{Barbara Dix Grimes}

People on Buru use several strategies to refer to geographical features on the landscape of their island. As on other eastern Indonesian islands, certain places are designated anthropomorphic metaphors, conceptualizing the island as a body. On Buru the large bay in the east (Kayeli Bay) is the "face" of the island. The range of mountains running east-west just to the south of the lake is called the "backbone of Buru island". Kak Pala Madat, the tallest mountain, towering $2,735 \mathrm{~m}$ high in the north-west of the island, is a "knee".

Another strategy is to name places after some characteristic feature. Two days' walk inland from the town of Leksula on the south coast is the village of Fakal where my husband and I first lived on Buru. Fakal, we soon found out, was the name of a large tree located near the village. A place in the jungle we often walked through was appropriately called fraga lale ("millipede centre"). ${ }^{1}$ We were told stories about a former village simply called Kabut ("mud"). Other Buru places are known in reference to significant events which occurred on those spots, such as a previous village named Ehu Molo ("Ehu Drowned") where a man named Ehu drowned, or a spot in the jungle that has come to be known as Geba Rohin ("People Bones") where burnt human bones were discovered after a murder. Places are also referred to in terms of land use, such as "Fallow Garden of Individual So-and-So". If people migrating to a different place on the island have not moved far, they may keep the same village name and some places thus come to be known as the location of "Old Village Such-and-Such".

The rivers and many streams on the island are all named and are culturally significant features of Buru geography. Many villages are named after nearby rivers or springs, such as Wae Katin ("Pandanus Water"), Wae Reman ("Long Water"), and Wae Haa Olon ("Headwaters of Loud Water"). Rana ("lake") is the name used to refer to the lake in the centre of the island as well as to several named villages surrounding the lake. Because this general area around the lake is as far "upstream" as one can go on the island, Rana is also a metonym for the interior of the island, symbolizing the cultural value of upstream over downstream, of the mountains over the coast.

In addition to being named and assigned value in these ways, places are also evoked in defining certain social relations. My purpose here is to explicate how these Buru places and relations come to "stand for" each other. Two sets of 
relation will be of significance. One relation is metaphorically mapped from the imagery of a plant where the "trunk and roots" (lahin) stand in contrast to the "leaf tips" (luken). This botanical model provides a conceptual model for causation in that roots are considered to be origins, sources and causes, while tips are consequences, results and effects. This model also structures Buru notions about life and prosperity as growth which proceeds from "roots" to "leaf tips". The second relation is constructed through another set of binary categories used to establish an order of precedence or seniority: the terms "elder" (kai) and "younger" (wai). As with the root-tip relation, temporal sequencing is a crucial element in the construction of this relation, for both roots and seniors precede tips and juniors. However, there is also a significant difference in that tips come from roots, but juniors do not come from seniors. Things categorized as senior and junior are conceived of in varying ways as units with some kind of commonality (like a common origin), but because one unit is differentiated as being prior and the other as subsequent the two units are distinct. But, again like the trunk-tip relation, the elder-younger relation is also asymmetrical in that an inherent inequality is built into the relation. Buru people overtly express that seniors are always superior to juniors and they repeatedly remind juniors "not to forget" they are juniors and to treat their seniors with respect. When the two categories elder-younger are applied recursively to multiple units, a hierarchy of precedence is created with internal relations depending on a given, individual position within the hierarchy (see Figure 1). All those elder must be respected, all those younger must show respect.

\begin{tabular}{|c|c|c|c|c|c|c|c|c|}
\hline elder & $>$ & \multicolumn{2}{|c|}{$\begin{array}{l}\text { younger/ } \\
\text { elder > }\end{array}$} & $\begin{array}{l}\text { younger/ } \\
\text { elder }\end{array}$ & $>$ & \multicolumn{2}{|c|}{$\begin{array}{l}\text { younger/ } \\
\text { elder }>\end{array}$} & $\begin{array}{l}\text { younger/ } \\
\text { elder }\end{array}$ \\
\hline
\end{tabular}

Figure 1. A hierarchy of precedence (from Fox 1989:52)

These two relations then are the relation of origin (cause and effect), expressed through the metaphor of "trunk" and "tip", and the relation of precedence expressed through "elder" and "younger". Two different kinds of places are culturally constructed with these relations on Buru: "origin places" and "taboo places".

\section{Origin Places}

In using the phrase "origin place" the relation of origin is immediately obvious, but to understand what this means it is necessary to refer to Buru kin groups called noro. A noro is the highest level political structure in Buru society, as well as being the exogamous unit. Internally a noro can be composed of a varying number of lower level units called "house-circles" (hum lolin). Both these groups 
are conceived of as bounded units in which individuals are socially located at birth. Social movement occurs at marriage when women "cross the threshold" (suba), leaving their natal noro, to "enter" (rogo) the noro of their husband. Because sisters leave while brothers "stay" (defo) and their wives enter, the permanency of the noro is defined by the males who remain in it for life.

In the discourse of inter-ethnic relations on the island, people who belong to these noro consider themselves "original" or "indigenous" to the island, using the term orang Buru asli in the Ambonese Malay lingua franca or in Indonesian. The rhetoric differentiates around 43,000 orang Buru asli from over 60,000 immigrants who have settled on the coast of Buru maintaining their diverse cultural and linguistic traditions. Some of these immigrant groups have arrived recently, others have been on the island for several centuries. Here my focus is on the minority native population, the so-called orang Buru asli, whose traditions have historically had the longest contact with the island. Today these people live both on the coast and in the mountainous interior of the island. They are socially divided into around 35 noro of varying sizes and speak an Austronesian language which they refer to as "the voice/speech of Buru island" (li fuk Buru), or in Indonesian, Bahasa Buru. ${ }^{2}$ On the coast there has been a history of contact with Islam since the days of the Sultanate of Ternate in the sixteenth century. Consequently, some of the native Buru people who live on the coast, as well as many of the immigrants, are Moslem. There has also been a history of contact with Christianity in the general region since the sixteenth century when the first Europeans arrived. However, Buru island was of little significance to either the Portuguese or Dutch traders, and contact with Europeans remained minimal. Around the turn of the twentieth century, relatively late in the colonial period, Dutch missionaries went to Buru. Subsequently Christianity has been adopted by various segments of the native population living both on the coast and in the interior of the island. In the discourse of ethnicity, however, these internal religious differences among the native population are not at issue. There the primary criterion is belonging to a Buru noro.

In defining itself in this way, the native Buru population can appear to be a unitary whole in contrast to the non-native immigrants on the island. However, any totalizing cohesiveness is found only in discourse, for there is no centralized political or ritual system unifying the different noro on the island. Buru people themselves describe their situation as one in which "each noro governs its own noro" (noro saa perinta tu nake noro). As a whole, their society is defined by networks of inter-noro relationships which can be characterized as much by alliance and marriage as by hostility and fighting. But regardless of whether two noro are momentarily focused on exchanging women in marriage or fighting each other in warfare, the relationship is predicated on a continual striving for symmetry, for the Buru ideology of inter-noro relations is "a person replaces a person" (geba gati geba). 
This principle applies equally to the loss of women in marriage as it does to the loss of men in warfare. When a noro loses a woman as a bride to another noro, she must be replaced although there are several ways this requirement can be fulfilled. One option is to replace her immediately with an incoming woman from her husband's noro. This occurs when the two noro agree that a marriage should involve "exchanged maidens" (emhuka eptukar). A second option for replacing a bride is to "return a child" (anat saa oli), by giving one of her own children back to her natal noro "to replace its mother" (gati nak ina). Finally, a bride could be replaced by bridewealth, giving her natal noro the potential to "pay for" (sili) an incoming bride at a later date. Similarly, when a noro loses a member at the hands of someone in another noro through murder or manslaughter, that loss must also be "paid for". "Revenge killing" (kalungan) is a legitimate way to reciprocate the loss and is only complete when there are an equal number of deaths in each noro. Alternatively, the bereft noro may decide to "make peace" (puna damen) and request that a child from the offending noro be given to them to "pay for the blood" (sili rahan). So in both warfare and marriage, relations between two noro are settled only when losses have been compensated. The underlying potential for equality exists in inter-noro relations because there is no system of "generalized exchange" nor any other system permanently ranking noro in fixed asymmetric relations. Furthermore, when the loss of a noro member produces an asymmetric relation between two noro because of an outstanding debt of a life, compensation restores the equilibrium of inter-noro relations.

In contrast to these relations there are other Buru relations which are permanently asymmetric. Such relations are found within a noro where "elder" and "younger" categories of precedence apply at various levels, creating internal hierarchies. These terms rank same-sex, same-generation kin within a house-circle; co-wives of the same husband; husband and wife; and the various house-circles within a noro. As social groups, the house-circles are assigned precedence on the basis of origin narratives which relate the timing of their relative establishment. Because the first settlement, the first house-circle, of a particular noro is considered to have been at the headwaters of a stream, the ranking of house-circles tends to be geographically objectified along the river. Elder house-circles were established before and upstream to younger house-circles established later and downstream. An ordering of precedence thus flows from elder to younger, from upstream to downstream, from the headwaters in the mountains at the centre of the island to the periphery of the island at the coast.

When an older couple came to visit their married daughter, I was informed by people in our village that the husband was the eldest male sibling of the eldest house-circle of the Gewagit noro. Actually it was his own Gewagit kinsmen who repeatedly stressed the man's precedence within his house-circle and the precedence of his house-circle within their noro. "There is no one elder than 
him", they told me. "He is 'on top' (ringe fi saka), all others 'descend seaward, descend seaward' (toho lawe, toho lawe)." As I enquired I found that his significance to his kinsmen was based exclusively on his structural position of elderliness. He was not a "titled" leader, not a great warrior, nor any kind of ritual specialist, for on Buru these social positions are neither hereditary nor based on primogeniture. The reason for the respect shown this man by his kinsmen was simply and sufficiently because he was the eldest of the eldest. By telling me and reminding everyone that he was the most "upstream" of all Gewagit males, they were in fact "not forgetting" his seniority and precedence, a precedence objectified along the river system.

Summarizing the nature of external and internal noro relations, it could be said that external noro relations are based on a very careful "bookkeeping system" for keeping track of lives lost, while internal noro relations are based on an equally careful "precedence system" for keeping track of who is elder and who is younger. Yet Buru noro are more than just a means of keeping track of people. A noro gives people more than just a name, it provides an ideology as well. In considering how Buru people portray their social world, the noro is central because the Buru rarely present an image of a unified Buru society. Rather, they talk very frequently about their particular noro, the importance of their noro, the uniqueness of their noro, the past glories of their noro. In a certain sense, their social world is their noro. Such noro-centric discourse resembles what Ricoeur (1986) has called a social imaginaire, referring to the discourses by which a society provides itself with an ideological stability and identity through representing or recollecting its "foundational symbols" (Kearney 1989:21-22). In all the Buru discourse about noro there are in fact several foundational symbols which people continually use in recollecting who they are. These symbols are concerned with origins, for noro are like "origin groups" in other eastern Indonesian societies:

[W] hat they claim to share and to celebrate is some form of common derivation. This derivation is socially constructed and may be variously based on the acknowledgment of a common ancestor, a common cult, a common name or set of names, a common place of derivation, and/or a share in a common collection of sacred artefacts (Fox 1990:3).

One of the most significant foundational symbols of a noro is its founder. While the present-day members of a noro are conceived of as descendants or "tips" from its founder, this does not mean founders are human ancestors, for in Buru cosmology they are distinct from and superior to humans. ${ }^{3}$ In the distant past, during the founding times of society, these founders were visible but are no longer so. Each founder is unique with a unique name, all of which contributes to the uniqueness of each noro. Some of the founders are female, some male. Some were autochthons who miraculously "appeared" on the island, while others 
are said to have come to Buru by boat. But regardless of whether they just appeared out of nowhere or arrived from elsewhere, each founder is associated with a unique river or stream on the island - a "founder stream". Beside this stream there is a further place of importance called the "place of the planted [house] pole" (tean elen). For autochthonous noro, the "place of the house pole" is at the spring in the mountains where the founder is said to have appeared. For non-autochthonous noro it is the place where the founder established him/herself after arriving on the island, at the headwaters of the stream or river the founder walked to after leaving the boat, often where the founder was given land by autochthons. In addition to the stream and the place of the house pole, the location of the founder's "boat disembarkation place" (waga enohon elen) and the name of the boat are also important foundational symbols for non-autochthonous noro.

Today many noro have a ritual house (near their "place of the house pole") in which various heirlooms belonging to the noro are stored. Typically these include ruling cloths and other objects of noro history, and contrast with bridewealth objects which belong to specific house-circles and can be given away to other noro in a marriage transaction. Bridewealth objects - like sisters - circulate, while these noro heirlooms - like brothers - stay in the noro. The significance of this ritual house, however, is not merely as a place for storing antiques. Through these structures people's places of origin and their connectedness to the island are made visible.

It is through this discourse of place that people construct the difference between natives and immigrants, between the "people of Buru island" (geb fuk Bururo), the so-called orang Buru asli, and "people from across the sea" (geb fi lawe). In certain regards, the kin groups of immigrants from nearby islands look structurally and functionally like Buru noro. Nevertheless, they cannot be Buru noro; their members cannot be "people of Buru island" because they have no connection to a founder's "stream" or "planted house pole place" on Buru. 4

This discourse about place can be considered a noro's sacred foundational narrative. Knowledge about a noro founder, the stream, the place of the "planted house pole", the boat name and the place of the boat disembarkation is in fact held with great reverence. Only noro members have the right to "open" the "story" (endohin) about their origins and they must always take care to "hide" (foni) the story. After wondering when some of these wonderful stories would be "opened" to me, I came to realize that in fact I had already heard many of them many times, only they had not come in the form I was expecting. These "hidden" stories turned out to be neither secret nor sophisticated; they were simply the names and the places concerning each noro's origins. In reality, many people know the sacred names and places of other noro. From a Western perspective, the stories can hardly be said to be "hidden". And yet from a Buru 
perspective where the primary purpose of hiding anything is to protect it from loss, each noro does indeed keep its sacred origin story well hidden.

In comparison to the eloquent poetry of lengthy origin narratives in other eastern Indonesian societies, the paucity of these Buru origin stories is striking, yet these very features reflect a consistency with other Buru values. Valeri (1990) has noted that in contradiction to certain anthropological generalizations, for the Huaulu on the island of Seram near Buru, "elaboration is not considered as more valuable than simplicity". In contrast to the wordiness and powerlessness of the present and of less important kinds of Huaulu knowledge, the simplicity of knowledge from the mythical past is proof of its superiority. This notion is reflected on Buru as well. Furthermore, it is in public situations, in formal speeches, that people attempt (and are expected) to be eloquent and profuse. Buru origin narratives are not elaborate, nor are they meant for public performances. They are meant to be hidden, preserving the simple and sacred knowledge of the distant past.

These narratives are more thorough than just revelations of the past; they are also scripts for contemporary action. In times of difficulty individuals can "return" to their origin place to pray (esmake) and request blessing from their founder. The men who "guard" the origin place of the Mual noro in a village near the Wae Brapa River, ${ }^{5}$ told me of two recent cases where kinsmen had come to their village seeking blessing from their founder. In one case, a blind Moslem Mual man had come across the sea from Ambon, walked with assistance for four days up treacherous mountain trails to get to the origin place where he made a sacrifice of money to the Mual founder, requesting to be cured of his blindness. In the second case a Christian Mual man living on the coast of Buru went back to the origin place to seek blessing from the Mual founder because of a labour contract in which he was building a government airstrip. The rare bit of flat land on the coast where various outsiders and government officials had proposed to build this airstrip happened to be the "boat disembarkation place" of the founder of the Mual noro. When work on the airstrip repeatedly failed, this man went back to seek the blessing of his noro founder, so the project would succeed.

This means that these places not only represent past origins, they also represent present sources of life and blessing. This is clearly reflected again in an earlier description by the Dutch missionary, Schut (1918:127), who referred to Wae Brapa as a small river in the interior of the island where one found the "consecration place" (gewijde plaats) of the "Mual clan" (Moeal-stam). Although those are Schut's terms, not mine, they clearly reflect what Wae Brapa signifies. In a description of Buru marriage, Schut (1918:125-140) also recorded a formal speech given by a Mual elder at the time a Mual "maiden" was to leave her natal 
home as a bride. The speech began with praise for the life that flows from Wae Brapa: 6

Barkate, Wae Brapa!

Da ba ila filim dae,

da ba pola filim dae;

tu nak mokin di leluke,

tu nak bawa omon gilate;

nak kawaan lahin sin le-leret,

lahin tane eflawa.

Nangan lawe pa man laut

nangan lawe pa man olat

olat da ba emngesa tuha

laut da ba emngesa tuha.
Blessed Wae Brapa!

Flowing from upstream,

bursting forth upstream;

with its fine-branched mokin,

with its shiny bawa leaves;

its tall bamboo,

and radiant trees.

Its opening downstream flows to the ocean, its opening downstream flows to the sea; the sea becomes one with it, the ocean becomes one with it.

But it is not only botanical life that flourishes because of Wae Brapa, the life of those in the Mual noro does as well. Remembering that the young bride would be taken to an unfamiliar place, Schut (1918:129) comments on the elder's speech:

The meaning is this: The young girl is departing from the Wae Brapa River where she was born. This water is sacred to her. If she becomes ill at her new residence, they must bring her back to the Wae Brapa River so that she can be given this water to drink, and so she can be bathed in this water [my translation].

For individuals of the Mual noro, Wae Brapa objectifies their relation to their origins, to their source of life and success. Wae Brapa is a place on the landscape, a stream in the mountains of Buru, but it is also a "foundational symbol". It is the place that people of the Mual noro celebrate when recollecting who they are.

From narratives about place, people of a given noro also construct their connection to a well-defined territory surrounding their place of origin. This territory is divided with each house-circle having responsibility for a given portion. As "masters of the place" (geba neten duan), other people must come to them to request permission to make gardens or to hunt there. Today there is a far from perfect correlation between places of residence and places of origin because people frequently migrate to other parts of the island. When undesirable consequences occur, such as the many deaths of a "big dying" (enmatan haat), people see it as essential to "drop the bad place" (tatak neten boho) and move on to a different place. But even if people have migrated and do not live on their land, they still inherit it by virtue of belonging to their house-circle and they still control rights over its use. And they may - even after spending several generations away - eventually return to live there. 
It is in the context of these migrations that Buru people reconstruct the more recent past with narratives tracing their forefathers' footsteps across the landscape. This tracing is very complex and individualized, for people of a single noro or even a single house-circle do not all live in the same place. Furthermore, when villages are abandoned, the people do not always move as a cohesive group. Bad inter-personal relations within a village are often the motivation for a migration or the perceived cause for a "big death" precipitating a migration. So a village often splits up, some households going in one direction, some in another. The following is a translation of a story about the migrations of her family told to me by a woman approximately sixty years old. I estimate the time depth to be eighty to one hundred years at most.

Our grandfather lived at Wae Brapa. There people of the Mual [noro] and the Gebhain [noro] married each other and they "entered religion". After a "big dying", they split up. Some went to Wae Katin, some to Wae Sam Belen. At Wae Sam Belen there was a "big dying"; they moved sideways to Ehu Molo. That was the time of the elder brother of [a man I knew]. People paid [Dutch] taxes then. An Ambonese pastor was at Ehu Molo. They built a GPM church, ${ }^{7}$ but people started dying and the pastor left. [A man who came to be a leader in the SJA church ${ }^{8}$ ] started going there, but because so many died, people moved on to Wae Bunan. At Wae Bunan there was no church, but SJA services were held in the house of [another man's] mother's brother. Then people moved on to Negriatlale. Three times they built SJA church buildings there but then there was a big dying. ${ }^{9}$ People split up, some went to [three existing villages] and some went to build [three new villages, one of which was the village we were in].

The information I requested from my informant was about places and village migrations, not church buildings. But as this narrative (as well as other narratives I recorded) clearly shows, in the more recent past since Christianity was introduced in the interior of Buru, church buildings - especially named church buildings (like Betania or Marinata) - have come to be another metaphor of time and place. Now people's movements across the landscape and through time can be referenced by church buildings. Perhaps this is because named church buildings create an easy device for remembering the complex histories about the migrations of great-grandfathers and grandfathers across the landscape. Still this knowledge of the recent past is actually far less important and much more forgettable than knowledge about the distant past which is preserved and hidden in the simple narratives of noro origins. 


\section{Taboo Places}

The Buru places considered in this section are called net koit, a phrase meaning "avoidance place" or "taboo place". Avoidance here does not mean that these places are places to be avoided; rather, when an individual is at such a place, avoidances or taboos must be observed. There are numerous "taboo places" on the island; they are of various sizes and their taboos are varied. As people frequently comment, "many different places, each has its own taboo" (neten-neten tu nake koin). ${ }^{10}$ This means that to walk through the jungle to go to the garden, to go to a different village, to go hunting, or even just to collect firewood, individuals often need to know numerous taboos associated with numerous places.

In these instances the discourse about place concerns taboo. People often talk about these places to instruct their children (as well as outsiders) and to remind themselves how to act. "If we do not follow a taboo, if we 'jump over' (tinggao) it", people say, "sooner or later bad consequences or punishment will beat us (baut paha kita)". Like the taboos, these punishments vary. They can be "big" or "small" and people may "carry the punishment on their backs" (wada baut) until they die or their children die. In talking about taboos often people also mention conventionalized ways to get around a taboo, ways to accomplish the same thing while avoiding the undesired behaviour. The general pattern for talking about "taboo places" is to combine all these elements. First the place and the taboo are stated, then the punishment, and finally the alternative action is described.

For example, when people talk about a taboo place at a stream called Wae Gogon they say,

The taboo of that place is that we cannot say "mosquito" (senget) or "the biting thing" (inhadat). ${ }^{11}$ The punishment for "jumping over" this taboo is that mosquitoes will bite us and we will not be able to sleep. Instead of saying "mosquito" at Wae Gogon, say "young girl" (anafina emhuka).

Another example pertains to the lake at the centre of the island. It is taboo to say the word emhein ("wave") there, because waves will come up and anyone on the lake in a canoe will drown. Instead of saying emhein, people should say ahut to refer to waves.

Some places have non-linguistic taboos as well as linguistic ones. To cross the Wae Fakal stream, a person must not wear a hat. The punishment for doing so: great wind, rain and floods. While people may collect water, bathe, wash clothes and dishes at Wae Fakal, children are not permitted to play there.

The largest taboo place on Buru is called Garan, an area between the lake in the centre of the island and the north coast in the vicinity of the Wae Nibe River (see Map 1). There are no villages in this area and it requires two days to walk 
from one side to the other. It's taboo: do not speak the Buru language. The punishment: disaster will strike, wind and heavy rain will come, sickness will break out. How to avoid the taboo: instead of speaking the Buru language, speak the Garan language (Li Garan).

The phenomenon of a "taboo language" on Buru was noted by a colonial official in 1933 (Jansen 1933). Linguistic and social aspects of this "language" have been discussed by C. Grimes (1991:40-42; also Grimes and Maryott 1994), including the effect of this and other localized taboos on dialect variation. Grimes notes that technically Li Garan is neither a dialect of Buru nor a separate language. It can be considered a special speech register developed entirely around taboo:

The syntax of Li Garan is the same as that of the Buru language. In looking at the lexicon, one can generalise that content words (such as nouns and verbs) tend to have a very general Li Garan term substituting for both generic and specific terms in the common Buru register. Functors (such as prepositions, deictics, aspect markers, verbal auxiliaries, pronouns, numerals, discourse markers) tend to be the same in the two registers (C. Grimes 1991:41-42).

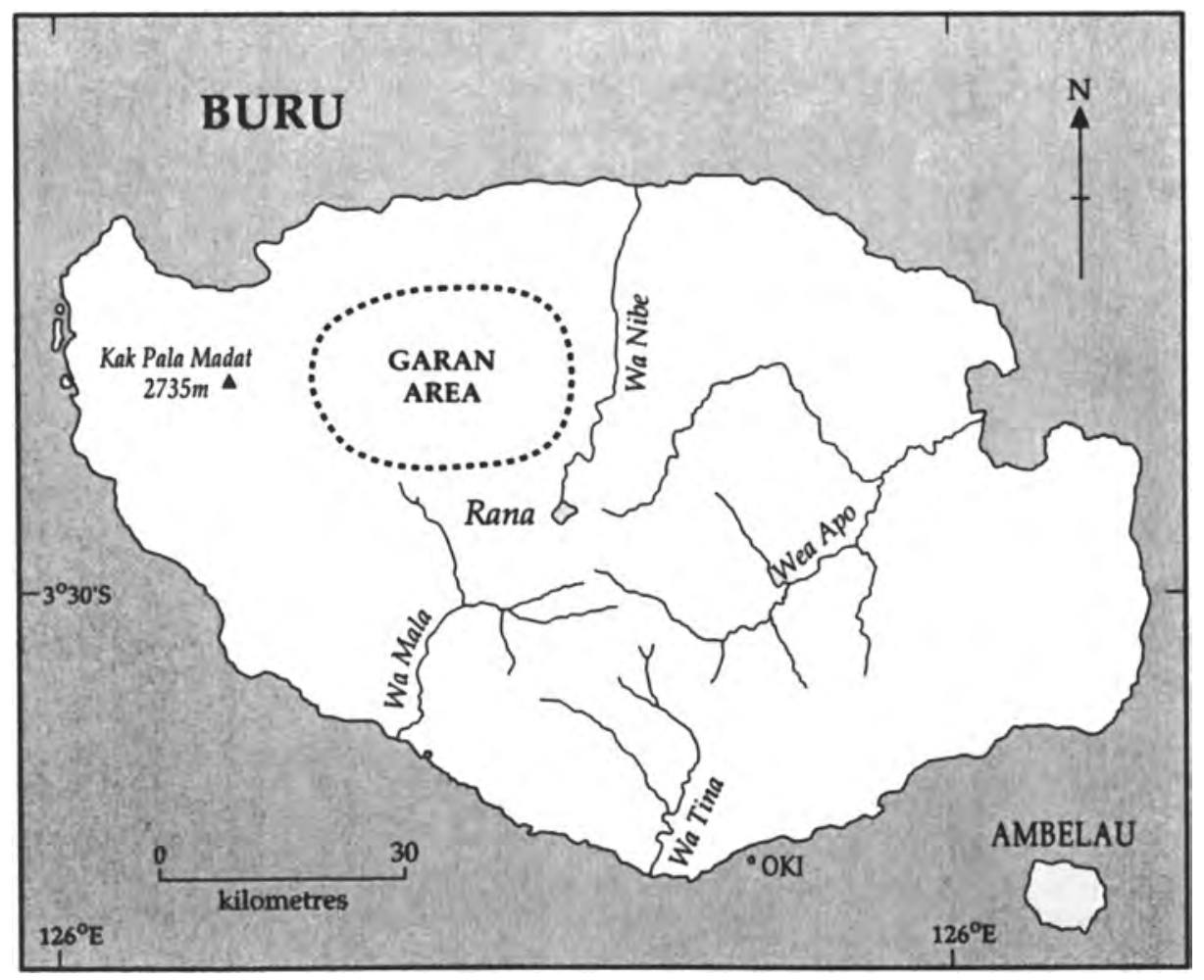

Map 1. The island of Buru 
People who live around the lake teach their children to speak this language from the time they are very small so that they will know it when they are in Garan. To speak Li Garan is greatly valued; people also use it as a secret language away from Garan. The relevant point is that Li Garan functions like other Buru taboo behaviour: it is a way around a taboo. As Buru people quickly point out though, it is not that people must speak Li Garan only in Garan, nor that they can only speak Li Garan in Garan. People can speak Li Garan wherever they like. And we were often assured that visitors to Garan who do not know Li Garan may speak Malay, English, Chinese or indeed any language other than the Buru language. That is the taboo of the place.

The question to ask not only about Garan, but about all "taboo" places, is why taboos are required there. From Buru cosmogony it is clear that the Buru landscape is inhabited not only by visible humans but by non-visible beings as well. They are conceived as having certain commonalities, and the same term used to refer to humans (geba) is also used to refer to some non-visible beings. Both kinds of "creatures" came into being through the supra-human noro founders said to have given "many births". The founders first gave birth to spirit beings who were initially visible but became non-visible. (Even non-visible, they remain agentive beings and can be the cause of good as well as bad outcomes.) ${ }^{12}$ The founders then gave birth to humans, thereby establishing their position as the origin or source of the people belonging to their noro. The narratives make clear the temporal sequence is of "spirits first, then humans"; in other words, elder spirits and younger humans.

In certain places in the jungle, spirits called "lords of the place" (geba neten tobon) are especially important because they are considered to be "owners come masters" (duan) of the wild animals in their domain. Just as human owners in the village feed their animals, these spirit owners in the jungle feed theirs. The masters of the wild pigs and deer are specifically called (sanane), while the masters of the cuscus and birds are called (geb rawa). There are many sanane and geb rawa throughout the jungle, and people know their names and the specific trees in which they live and where they feed their animals. ${ }^{13}$

Since these spirits are the masters of the wild animals, hunters must show respect and offer prayers to them saying, "Please, Sanane, give me a wild pig today" or "Please, Geb Rawa, may you let a cuscus get caught in my trap". In certain places, so as not to offend nor to make the "lord of the place" aware of their intent, hunters do not say the name of the animal they are hunting. This creates one motivation for the prolific taboos associated with hunting, which are always restricted to a certain locale: "In such-and-such a place do not say "pig'. If you do, you will not catch a pig." It is important to be quiet around those trees in the jungle considered to be the "houses" of the "lords of the place" in order to avoid annoying the lords or making them aware of one's presence. 
When walking near these places parents remind their children in forceful whispers, "Don't be loud, it's taboo" (Bara hean moo, tu koin). The goal is to walk by these taboo places as quietly and quickly as possible without causing any "offense or wrong" (sala).

At Buru taboo places the establishment and maintenance of proper relations is being enacted through a high degree of avoidance behaviour. Relations (particularly asymmetrical ones like elder-younger) are never taken for granted, but are continually discussed, evaluated and re-expressed through behaviour fitting to the relation. In addition to the relation between spirits and humans, numerous other Buru relations are also constructed in terms of avoidance. Beside "taboo places" there are "taboo things" (ii koit) like the heirlooms of the noro, and "taboo people" (geb koit), certain affines to whom individuals must "show custom" (tahu adat) or proper behaviour by avoidance. What is constructed in all these taboo places, people and things is an asymmetrical relation predicated on separation and which demands social distance rather than social intimacy in people's behaviour.

On Buru social distance is not externalized through positively defined behaviour ("Do this to show respect"), but through avoiding behaviour that suggests familiarity and would thus negate the relation ("To show respect, don't do this [behaviour suggesting familiarity]"). This is particularly clear in the behaviour required towards affines. There are numerous things one cannot do in the presence of affines, who are considered taboo (geb koit). But these "taboo people" are contrasted with others who are "easy people" (geb dape), people with whom familiarity and intimacy is possible, where relations require no social distance or avoidance. The spirits in the jungle are analogous to "taboo people". There are numerous things one cannot do in their presence. Being non-visible, however, these spirits are known through the metonym of place.

It is important to know these places, because behaviour that "forgets" or negates a proper relation will have unfortunate consequences. An "offence" (sala) toward spirits who are "elder", and in some cases the previous owners of animals, can "close" (tregu) offenders in their pursuits of life: they will have no success, their children or other family members may become ill and die. In seeking the cause or "root" (lahin) of an illness, the past behaviour of the individual (and of his or her relatives) at all known taboo places is reviewed to discern if some offence was committed. ${ }^{14}$ If there was an offence, the situation is rectified through prayers and requests for forgiveness, although sometimes it is necessary to sacrifice a chicken or pig as well. In a similar way, people also re-establish proper relations between themselves by "asking forgiveness and giving gifts of cloth" (eslauk) when offences have been committed. So in both the visible and the non-visible Buru world, distinct relations are properly 
revealed through distinct and distancing behaviour. Forget this and "punishment" will strike.

\section{Conclusion}

The Buru places discussed here are spaces where social and cosmological relations of origin and precedence are externalized on the island's landscape. At springs in the mountains, individuals and groups find their origins and their source of life and blessing. Along the river systems the precedence of house-circles flows from upstream to downstream. At taboo places precedence is behaviourally enacted by human beings cosmologically junior to spirits. Through these places and relations Buru people define themselves by continually re-affirming their place in society.

\section{References}

Fox, James J.

1989 Category and complement: binary ideologies and the organization of dualism in eastern Indonesia. In D. Maybury-Lewis and U. Almogor (eds) The attraction of opposites: thought and society in the dualistic mode, pp.33-56. Ann Arbor: The University of Michigan Press.

1990 Hierarchy and precedence. Working Paper No. 3, Comparative Austronesian Project. Department of Anthropology, Research School of Pacific Studies, The Australian National University.

Grimes, Barbara Dix

1991 The development and use of Ambonese Malay. Pacific Linguistics A18:83-123.

Grimes, Charles E.

1991 The Buru language of eastern Indonesia. PhD thesis, The Australian National University, Canberra.

Grimes, Charles E. and Kenneth Maryott

1994 Named speech registers in Austronesian languages. In T. Dutton and D. Tryon (eds) Language contact and change in the Austronesian world. Berlin: Mouton de Gruyter.

Hocart, A.M.

1952 The northern states of Fiji (Occasional Publication No. 11). London: The Royal Anthropological Institute of Great Britain and Ireland.

Jansen, H.J.

1933 Gegevens over Boeroe (1928). Adatrechbundels 36:463-489.

Kearney, Richard 
1989 Paul Ricoeur and the hermeneutic imagination. In T.P. Kemp and D. Rasmussen (eds) The narrative path: the later works of Paul Ricoeur, pp.131. Cambridge, MA: MIT Press.

Ricoeur, Paul

1986 Lectures in ideology and utopia (edited by G.H. Taylor). New York: Columbia University Press.

Schut, J.A.F.

1918 Het huwelijk bij de Geb'emliar op Boeroe. Mededeelingen vanwege het Nederlandsch Zendelinggenootschap 62:16-35, 125-140, 197-210, 296-308.

Valeri, Valerio

1990 The genres of knowledge in Huaulu (Seram). Paper presented at Conference on Halmahera Research and its Consequences for the Study of Eastern Indonesia. Koninklijk Instituut voor Taal-, Land- en Volkenkunde, Leiden, October.

\section{Notes}

1 All vernacular terms of the Buru language are in Palatino italics, while all Indonesian terms and those of the Ambonese Malay lingua franca (see Grimes 1991) are in Helvetica italics. The occasional French and Fijian terms also appear in Helvetica italics.

${ }^{2}$ While Buru people emphasize that this is one language, they also recognize internal differences. Five major dialects can be distinguished (C. Grimes 1991:35-36).

${ }^{3}$ When Hocart described Lau categories of spirits in Fiji, he found that a class of spirits called $v u$ (which he also referred to as "gods") had as their chief characteristic "originating". He also noted "the Fijians are very careful to distinguish between the spirits of the dead and these [vu] gods" (1952:9). While admitting the difficulty of finding an adequate gloss for $v u$, Hocart referred to them as "founder-gods". The founders of Buru noro are similar. They are spirits, but not spirits of deceased human ancestors.

4 Other factors such as language and "custom" (adat), are also important in group identity. But from a Buru perspective, the primary factor is origins. Other people speak other language because they have non-Buru origins, not the other way around. In other words, it is not because they speak other language that people are attributed non-Buru origins.

5 A tributary of the Wae Mala River.

6 In this text I have changed Schut's original orthography to reflect current orthographic practices on Buru. Many of these differences parallel changes in the Indonesian orthography.

7 Gereja Protestan Maluku [Protestant Church of Maluku], the heir of the Dutch colonial Indische Kerk in Maluku.

8 Sidang Jemaat Allah, the Indonesian branch of the American-based Assemblies of God Protestant denomination.

${ }^{9}$ Like any other buildings made out of native materials, church buildings have to be replaced or rebuilt every five to ten years.

10 When $-n$ is attached, the root koi- is nominalized and can be glossed as a noun: "the taboo" or "its taboo".

11 Both senget and inhadat are taboo-generated avoidance terms for "mosquito" which are fully assimilated into different dialects (C. Grimes 1991:35 and Grimes and Maryott 1994).

12 Other Buru names for generic categories of these spirits are jingi and setan, both originally from Arabic (C. Grimes, personal communication).

13 One place in the interior of the island was labelled on several Dutch maps as Sanane Puun ("Sanane Shrub"). 


\section{The Poetic Power of Place}

14 This behavioural review process that occurs whenever something bad happens contributes to the on-going creation of new taboos. If no obvious sala can be discerned, the misfortune must be because of some previously unrecognized taboo. The situation is discussed until those concerned reach some conclusion about the cause of the sala, effectively creating a new taboo. I suggest this also contributes to the idiosyncratic nature of many taboos, as the sala is discerned by examining the recent behaviour of those involved. What they did may have been very mundane and ordinary in other contexts, but it turns out to have been taboo in that place. 